\title{
Influence of Servant leadership on Project success with mediating role of Team building and moderating role of Trust in Pakistan
}

\author{
Sidra Yousaf* \\ Capital University of Science and Technology, Islamabad, Pakistan.
}

\begin{abstract}
The aim of the study was to explore the relationship between servant leadership and project success through the mechanism of team building; while trying to find out the moderation effect of trust. The data were collected from 120 employees in Islamabad Rawalpindi area through questionnaire from a sample drawn through convenient sampling technique. The data were analyzed through regression. The study findings suggested that Servant leadership has a positive relationship with project success, while team building also mediates the relationship between the two variables. Similarly, trust positively moderates the relationship between servant leadership and team building. The study concludes by discussing implications and future directions.
\end{abstract}

\section{Introduction}

Personality and leadership style are considered as major success factors for a project (Joslin and Müller, 2016; Turner and Müller, 2005). The servant leadership concept is given by Greenleaf et al. (1996) The servant as leader, where leaders are servant first. So, such leaders have link with ethics, virtues and morality (Parris and Peachey, 2013). Many recent researches have found that servant leadership reveals positive relation with organizational performance in terms of trust and quality relationship among subordinates and supervisors (Joseph and Winston, 2005; Seto and Sarros, 2016; Timiyo and Yeadon-Lee, 2016). This sets the background for good relations among such leaders and subordinates; also leading towards high performance appraisals and carrier opportunities (Miao et al., 2014).

Joslin and Müller (2016) have identified stewardship as one of the reasons for projects success. Servant leadership has attributes of stewardship, empathy, trust, empowerment, encouraging subordinates, listening, and decision making (Van Dierendonck and Nuijten, 2011).

In order to influence project performance positively other than triple constraints, project managers have to work on team building and for this they need to develop team trust. Team trust is also strongly associated with organizational performance (Costa, 2003). Based on the Cohen and Bailey (1997) research, process factor can directly impact the outcome into behavior and performance. Team building is selected as process factor, whereas trust is chosen for behavioral outcome and performance includes quality of work or project perfor-

*Corresponding author.

Email: sidra.yousaf79@gmail.com mance.

Studies are found in project management literature, on transformational leadership and its positive impact on project performance with the mediating role of team building by Aga et al. (2016). Comparison studies of servant leadership with association of transformational leadership are also made by Hoch et al. (2016); whereas, significance of team building and leadership and their impact on project success this have also been studied Bubshait and Farooq (1999). Therefore, the underlying process of servant leadership and its impact on projects success is not addressed properly in project managements literature.

Servant leader works as servant first in order to provide services to others and focuses more on organizational objectives rather than their own personal objectives (Davis et al., 1997; Greenleaf et al., 1996; Parris and Peachey, 2013; Russell and Gregory Stone, 2002). This has been supported by stewardship theory because stewards seek the organizational objectives (Davis et al., 1997), and this kind of attitude makes them emphasize on team building by the effective coordination among team members so that they can serve their clients as obligation. Servant leaders with the support of conflict management can enhance teamwork (Wong and Page, 2003).

Purpose of this study is to make contribution towards better understanding of servant leadership as project manager for enhancing team building with moderating role of trust and ultimately their impact on projects success. Assuming that servant leadership facilitates the team building concepts in return it positively affects the project success. Servant leaders are 
most trusted leaders for organizations (Greenleaf et al., 1996; Sendjaya and Pekerti, 2010).

\section{Literature Review}

\subsection{Project Success}

Typically project management is delivering of a product to the customer within time and budget constraints. But the research by Shrnhur et al. (1997) has highlighted the project success into four dimensions; Project efficiency dimension is considered as short term which has more about the process of project. Success in this dimension simply is expressed if project is done within specified time and budget. Impact on customers relies on customer satisfaction in terms of their needs which has been fulfilled. This can be gauged by checking to what extent the end user is using this product, is he looking for some more changes or updating the current product reveals how much the customer is satisfied. Business and direct success refers to the impact of a project on the organization. In terms of business how much profit did it make? Did it help in achieving ROI? The last dimension, Preparing for the future is all about identifying the future opportunities and skills required; getting prepared for the competitors moves. Therefore, project success is basically a concept of both short and long term. First dimension is only assessable in short term during the project execution. Second dimension is after a short time, when customer is using the product this may take few weeks or months. Third dimension can be assessed after making number of sales may take around years. Whereas, fourth dimension is also long term may take around four to five years. So, all these dimensions are time-dependant. Another research made by Belassi and Tukel (1996) posited that success and failure of the project dont have same criteria. There are some critical factors such as factors influencing project performance, team members, industrial or environmental factors. Project management institute (PMI) has defined the success in terms of quality, scope, time, cost and meeting stakeholders needs (PMI, 2008).

\subsection{Servant leadership}

Servant leadership was firstly introduced by Greenleaf (1977) under the title of The servant as leader which means who serves as a leader first. Contribution to Greenleafs research (Spears and Wagner-Marsh, 1998) identified several attributes including: listening, empathy, healing, awareness, persuasion conceptualization, foresight, Stewardship, Commitment to the growth of people, Building community. Revised servant leadership profile is explained by Wong and Page (2003) in which factors were listed, such as Developing and empowering others by looking into hidden tal- ents of others. They look at themselves as a superior and keep all the subordinates under control. Visionary leaders are able to inspire others. Servant hood by maintaining servant heart is able to make personal sacrifices. They are considered responsible as they do not blame others and understand the organization very well; Honesty in terms of keeping promises and commitments through honesty and empathy which builds the trust. They are courageous, listen to all, and involve everyone in decision making. This helps in team building.

\subsection{Servant leadership and project success}

Difference between transformational and servant leadership is the focus of leader basically; where transformational leader focuses on an organization and servant leadership focuses on followers commitment which ultimately is towards the achievement of organizational goal. Both of these leadership styles are dynamic in nature and both of them generate the high level of trust with just difference in focus as mentioned above (Russell and Gregory Stone, 2002). According to Flynn et al. (2016) servant leadership theory plays a role of self evaluation which positively leads to leader performance. Judge and Kammeyer-Mueller (2011) found that organizations would be preferring individuals with high core self evaluation as such individuals are very focused with job satisfaction motivation and performance. Four specific traits of core self evaluation found by Judge et al. (2003) were self-esteem, generalized self-efficacy, low neuroticism and locus of control. As Flynn et al. (2016) have said that self evaluation is positively related to leaders performance. Servant leadership works as servant first in order to provide services to others and focuses more on organizational objectives rather than their own personal objectives (Greenleaf, 1977; Parris and Peachey, 2013; Russell and Gregory Stone, 2002). Personality and leadership style is considered as major success factor for a project (Joslin and Müller, 2016; Turner and Müller, 2005). With the support of stewardship theory it is perceived that stewards seek to obtain the organizational objectives more rather than their self interest in turn it benefits organization in terms of profit (Davis et al., 1997). Servant leadership having stewardship as an attribute (Spears and Wagner-Marsh, 1998) plays vital role positively with project success. Hence with the support this literature following hypothesis is offered:

H1: Servant leadership positively influences project success.

\subsection{Team-building}

Team building refers to interventions such as problem diagnosis and solving meetings with use of con- 
sultant are designed to improve the efficiency of work groups (Woodman and Sherwood, 1980). Meetings based on the data collection, feedback of the data and action planning. Tannenbaum et al. (1992) has also said that intervention process is a set of activities helping individuals. Conceptual definition of team building is given by Buller (1986) in which a team building problem solving approach is presented; whereas, problem solving is team building activity to solve major problems and ultimately develop the teams capacity of problem solving. Dirks (2000) has said that the efficiency of organizational performance in terms of profit is based on how people learn, collaborate and interact with each other. He said that organizations are changing their traditional hierarchical structures into more dynamic nature team where every member works on a same goal, where manager with employees grow together. Study made by Klein et al. (2009) checked whether team building works? The results are very supportive of the idea that team improves the outcomes. Major components of teambuilding are Goal settings: developing of goals with the help of consultant. This approach can be strategic level or can be targeted on some specified productivity. Role clarification: this approach is basically concerned with the roles of the team members mainly involves negotiation skills or discussion among team members in order to reduce conflicts. Interpersonal relations: this approach focuses on the interpersonal relations in a team. This can be aimed to improve the trust among members and encouraging support and communication. Problem solving: this is about identifying the major problems, solving techniques and action planning. Goal setting and role clarification have larger impact on outcome.

\subsection{Servant leadership and team-building}

Team building is considered crucial for project manager to keep the team motivated for achieving their common goals Project is all about managing team so managers have to build up their team for successful projects (PMI, 2013). Based on Cohen and Bailey (1997) study, process factor can directly impact the outcome into behavior and performance. Team building is selected as process factor, whereas trust is chosen for behavioral outcome and performance, which include quality of work or project performance. Moreover the team building practices are important as they are used to enhance the trust among team members in order to promote the team cohesion (Fung and Cheng, 2016); as they proved in their research that both team trust and team cohesion influence project performance. In every project nature there is a leadership behind successful programs which heavily involves the skills of working together (Bubshait and Farooq, 1999). Characteristics of a servant leadership explained by Spears (1996) as they are more humble, they treat subordinates with un- conditional respect which helps in making work environment positive and enhance the intrinsic motivation. Such leaders easily earn trust because they place their followers above self- interest. They always make good relations through empathy, kindness and emotional intelligence. They easily gain co-operation by valuing team and involving others in decisions which provides the basis for team building. Hence with the support of the literature we can say that Servant leadership positively influences project team building and team building positively influences project success. Hence we can say:

H2: Team building mediates the relationship between servant leadership and project success.

\subsection{Moderating role of Trust}

Berry (1995) has said that trust is an important element for successful relation. Trust has multilevel view between individuals, groups and firms (Rousseau et al., 1998). Trust theory explained by Moorman et al. (1993) in market research relationships. This theory tells that trust is predicted by interpersonal factors. They defined trust as an intention of behavioral willingness. Crosby et al. (1990) have said that future sales opportunity is dependent on relationship quality such as trust. The component of experience influences the overall satisfaction, trust and commitment for customers. But trust and commitment have impact on future intentions (Garbarino and Johnson, 1999). Projects are more effective with maintaining high level of trust between participants (Smith and Rybkowski, 2012). Servant leaders are most trusted leaders for organizations identified by Sendjaya and Pekerti (2010). Based on Cohen and Bailey (1997) research, process factor can directly impact the outcome into behavior and performance. Team building is selected as process factor whereas trust is chosen for behavioral outcome and performance includes quality of work or project performance. According to Goh and Low (2013) organizations should adopt the servant leadership style to gain trust, which ultimately positively affects the results in terms of organizational commitment. Individuals prone to trust others are strongly associated with the highest quality relationships with support of social exchange theory (Bernerth and Walker, 2009) this theory is dependent on situation varying from person to person it does concern with managerial personalities and their subordinates personality in terms of social exchange. Trust in leadership will affect the team performance. Studies show that trust among team members appears positive with team performance and satisfaction (Costa, 2003). According to Spears and Wagner-Marsh (1998) servant leaders have attribute of trust in their personality and focus on the organizational needs more (Greenleaf et al., 1996). Hence with the support of this we can 
say.

H3: Trust positively moderates the relation between servant leadership and teambuilding

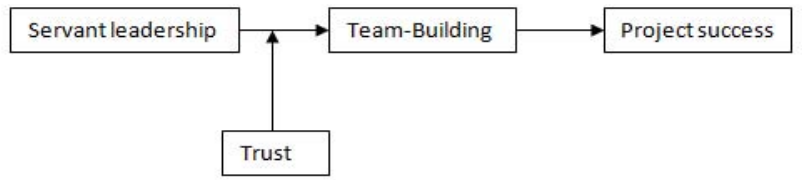

Figure 1: Model

\section{Methodology}

\subsection{Population and Sample}

The study targets the impact of servant leadership on projects success with mediating role of trust and moderating role of team building in project based companies located in Islamabad and Rawalpindi. 120 selfadministered questionnaires were distributed among private sector; only 100 respondents completed and returned survey. The demographics of the sample are summarized in Table 3.1.

Table 3.1: Demographics

\begin{tabular}{lc}
\hline Item & Frequency \\
\hline Gender & \\
Female & 50 \\
Male & 40 \\
Total & 90 \\
Level of Education & \\
First Degree & 15 \\
Master & 70 \\
PhD & 5 \\
Total & 90 \\
Experience & \\
$0-5$ & 50 \\
6-10 & 40 \\
Total & 90 \\
\hline
\end{tabular}

\subsection{Measures}

\subsubsection{Project Success}

This study uses the survey items of Robey et al. (1993) to measure project success in project management literature. This scale consists of 6 items, covering time, quality, performance, budgets and effectiveness. All the respondents assessed items on a likert scale of
1-5 from Strongly Disagree $=1$ to Strongly Agree $=5$. The reliability of the instrument was 0.829 .

\subsubsection{Servant Leadership}

In leadership style there are multiple factors to be measured as far as servant leadership is concerned instrument was adopted from Van Dierendonck et al. (2017). There are 18 items including factors such as calling, listening, empathy, healing, awareness, persuasion, conceptualization, foresight, stewardship, growth and community building. Sample question like 1. My manager gives me the information I need to do my work well. 2. My manager encourages me to use my talents. 3. My manager helps me to further develop myself. All the participants will asses on likert scale from 1-5. Strongly disagree to strongly agree. The reliability or Cronbachs alpha value was 0.856 .

\subsubsection{Project Team Building}

Instrument developed by Wong and Page (2003)was used for measuring team building. It contains 8-items. Sample like 1. I am willing to sacrifice personal benefits to promote group harmony and team success. 2. I evaluate and deploy team members based solely on their performance and capacity for serving others. 3. I encourage cooperation rather than competition through the group. This instrument is also measured against likert scale of 1-5. Strongly disagree to strongly agree. Its cronbachs alpha value was 0.823 .

\subsubsection{Trust}

Respondents completed all the 8 items, instrument developed by Gunia et al. (2011). Sample items were like 1 . The other party will try to be someone who keeps promises and commitment. 2. The other party will do what they say they will do 3 . In negotiations most other parties are basically honest. This instrument is also measured against likert scale of 1-5. Strongly disagree to strongly agree. The reliability was 0.889

\section{Results}

\subsection{Correlation}

The demographic variables consisted of age, gender, and work experience. Gender was coded 0 as male and 1 as female. Age was reported in years, and work experience was also reported in the number of years the participant had been managing projects. Results were considered significant at $\mathrm{p}<=0.05$. As shown in Table 4.1.

Table 4.1 presents inter-correlations among the variables. As predicted, significant and positive correlations exist among servant leadership, team-building, trust and project success. Servant leadership and 
Table 4.1: Correlations Matrix

\begin{tabular}{lccccccc}
\hline Variable & $\mathbf{1}$ & $\mathbf{2}$ & $\mathbf{3}$ & $\mathbf{4}$ & $\mathbf{5}$ & $\mathbf{6}$ & $\mathbf{7}$ \\
\hline Age & 1 & & & & & & \\
Gender & -.164 & 1 & & & & \\
Experience & $.657^{* *}$ & .011 & 1 & & & \\
Project success & .013 & .199 & .005 & 1 & & \\
Servant Leadership & .079 & .22 & .083 & $.625^{* *}$ & 1 & & \\
Team building & -.213 & $.280^{*}$ & -.28 & $.641^{* *}$ & $.367^{* *}$ & 1 & \\
Trust & -.153 & $.323^{* *}$ & .018 & $.628^{* *}$ & $.564^{* *}$ & $.754^{* *}$ & 1 \\
\hline
\end{tabular}

Notes: ** Correlation is significant at the 0.01 level (2-tailed), ${ }^{*}$ Correlation is significant at the 0.05 level (2-tailed).

project success were significantly correlated $(\mathrm{r}=0.625$, $\mathrm{p}<0.01$ ), and the team-building index was also significantly correlated with project success $(\mathrm{r}=0.641, \mathrm{p}<$ $0.01)$ and servant leadership $(r=0.367, \mathrm{p}<0.01)$. Positive correlation of trust with team-building $(\mathrm{r}=0.564$, $\mathrm{p}<0.01)$ and servant leadership $(\mathrm{r}=0.564, \mathrm{p}<0.01)$.

\subsection{Regression Analysis}

Hypotheses were tested using regression analysis. Hypothesis 1 of the study states that Servant leadership positively influences project success. Results of the hierarchical regression analysis are shown in Table 4.2. In step 1, only the control variables were included in the model. None of the control variables was found to be significant in explaining project success. The result of step 2 indicates that servant leadership has a significant and positive relationship with project success $(\beta$ $=0.625, \mathrm{p}<0.001)$ Hence, Hypothesis 1 has been accepted.

Hypothesis 2 proposes that team building mediates the relationship between servant leadership and project success. The results in step 1 of Table 4.3 indicate that the control variables had a negligible effect on team-building. On the other hand, servant leadership uniquely contributed $24.9 \%$ of the variance in team-building upon its addition to the model in step 2 . The results further show a strong and highly significant relationship between servant leadership and teambuilding ( $\beta=0.560, \mathrm{P} \mathrm{b} 0.001$ ) leading to acceptance of hypothesis 2 .

The true indirect effects via team building on the servant leadership lies between 0.1098 and 0.4659 , for these results zero wasn't present in the 95\% confidence interval. So, the effect of servant leadership on project success was partially mediated by team building.

Table 4.4 shows moderation results. The direct effect of servant leader on team building is significant with $.356^{* * *}$ as we as that of trust with team building with $.318^{* * *}$. Although, significant, but by adding interaction term, i.e. SL*Trust the effect of teambuilding enhances at $\beta=1.285^{* * *}$ leading to the acceptance of hypothesis three, i.e. trust positively moderates the relationship between servant leadership and team building.

\section{Discussion}

The purpose of the present study was to investigate the linkage between servant leadership and project success through the mediating role of team-building and moderating effect of trust. As predicted, we found a positive association between a project manager's servant leadership and project success. This finding shows that the project manger's leadership style plays an important part in project success. Essentially, a servant project manager motivates and inspires team members towards a holistic conception of project success, characterized by efficiency, effectiveness, and stakeholder satisfaction. This finding answers the call by Turner and Müller (2005), who underlined that the project management literature failed to give sufficient attention to the role of project managers' leadership styles. We also found that team-building is positively related to project success. Through these classic team-building practices, organizations and project managers are more likely to improve team members' knowledge about the project goals, roles and responsibilities, interpersonal communication, and problem-solving skills, which would in turn influence project success.

Second, and perhaps more importantly, we demonstrated that trust moderates the relationship between a project manager's servant leadership and team building. This is the first study that explicitly identifies the moderating role of trust in the relationship between servant leadership and team building. This finding suggests that project managers exhibiting servant leadership are more likely to create the team-building practices in a project environment that will help them to realize project success. These practices include project goal-setting, role-clarification, interpersonal relations, and problem-solving techniques, which together moti- 
Table 4.2: Regression Analysis

\begin{tabular}{lcccc}
\hline & \multicolumn{4}{c}{ Project Success } \\
Predictor & $\beta$ & $R^{2}$ & Adjusted $R^{2}$ & $\Delta R^{2}$ \\
\hline $\begin{array}{l}\text { Step 1 } \\
\text { Control Variables }\end{array}$ & 0.013 & -0.014 & 0 \\
$\begin{array}{l}\text { Step 2 } \\
\text { Servant leader }\end{array}$ & $.625^{* * *}$ & 0.391 & 0.382 & $.391^{* * *}$ \\
\hline $75 .{ }^{*} p<.05 .{ }^{* *} p<.01 .^{* * *} p<.001$. & &
\end{tabular}

Table 4.3: Mediated Regression Analysis

\begin{tabular}{lcccccc}
\hline IV & $\begin{array}{c}\text { Effect of Effect of M } \\
\text { IV on M } \\
\text { on DV }\end{array}$ & $\begin{array}{c}\text { Direct } \\
\text { Effect }\end{array}$ & $\begin{array}{c}\text { Total } \\
\text { Effect }\end{array}$ & $\begin{array}{c}\text { Bootstrapping Bootstrapping } \\
\text { Indirect } \\
\text { Effects LLCI }\end{array}$ & $\begin{array}{c}\text { Indirect } \\
\text { Effects ULCI }\end{array}$ \\
\hline Servant Leadership & .4928 & .6506 & .6506 & .2520 & .1098 & .4659 \\
\hline $\begin{array}{l}\text { Note. IV = Independent Variable, } M=\text { Mediator, } D V \\
\text { Confidence Interval. }{ }^{*} p<0.05 ;{ }^{* *} p=0.01\end{array}$
\end{tabular}

Table 4.4: Moderated Regression Analysis

\begin{tabular}{lccc}
\hline & \multicolumn{3}{c}{ Team Building } \\
Predictor & $\beta$ & $R^{2}$ & $\Delta R^{2}$ \\
\hline Step 1 & & \\
Control variables & & .023 & \\
Step 2 & & \\
Servant leadership & $.356^{* * *}$ & .240 & .217 \\
Trust & $.318^{* * *}$ & .379 & .319 \\
Step 3 & & & \\
SL ${ }^{*}$ Trust & $1.285^{* * *}$ & .432 & .052 \\
\hline Note: $N=101,{ }^{*} p<.05,{ }^{* *} p<.01,{ }^{* * *} p<.001$ & &
\end{tabular}

vate and empower a project team towards project success.

Trust is one of the mechanisms that will increase relationship between leader and follower. Leaders who are trusted by their subordinate or follower can easily develop sense of assurance and obligation in their follower and subordinate. Trust on leader can have an effect on many results of organization and based on much research trust is one of the significant elements of servant leadership, so servant leadership style is the best element for developing trust in the organization. Employees show further bond with each other that nurture empathy when they have trust in the organization and their leaders, servant leaders are supposed to be honestly concerned about the well-being of their dependents. Due to sensitive nature of the project servant project managers first aim will be project employee and when manager will trust and care the project employee the project success and performance will be automatically increased.

\subsection{Theoretical and practical implications}

The present study contributes to the project management literature by integrating leadership theory and a team-building model. The results of this study show that team-building interventions link the relationship between servant leadership and project success. This advances our understanding of servant leadership and team-building in engendering project success.

Due to short span of time only one mediator was examined, future study can develop the model and also test the other type of mediator like employee trust, 
knowledge sharing, and self-efficacy and for moderator test collectivism, organization culture and high power distance and employee ethical concern. Second, we collected the data at once i.e. cross sectional future research should collect the data in time lags.

\section{References}

Aga, D. A., Noorderhaven, N., and Vallejo, B. (2016). Transformational leadership and project success: The mediating role of team-building. International Journal of Project Management, 34(5):806-818.

Belassi, W. and Tukel, O. I. (1996). A new framework for determining critical success/failure factors in projects. International journal of project management, 14(3):141-151.

Bernerth, J. B. and Walker, H. J. (2009). Propensity to trust and the impact on social exchange: An empirical investigation. Journal of Leadership E Organizational Studies, 15(3):217-226.

Berry, L. L. (1995). Relationship marketing of servicesgrowing interest, emerging perspectives. Journal of the Academy of marketing science, 23(4):236-245.

Bubshait, A. A. and Farooq, G. (1999). Team building and project success. Cost engineering, 41(7):34-38.

Buller, P. F. (1986). The team building-task performance relation: Some conceptual and methodological refinements. Group E Organization Studies, 11(3):147-168.

Cohen, S. G. and Bailey, D. E. (1997). What makes teams work: Group effectiveness research from the shop floor to the executive suite. Journal of management, 23(3):239-290.

Costa, A. C. (2003). Work team trust and effectiveness. Personnel review, 32(5):605-622.

Crosby, L. A., Evans, K. R., and Cowles, D. (1990). Relationship quality in services selling: an interpersonal influence perspective. The journal of marketing, pages 68-81.

Davis, J. H., Schoorman, F. D., and Donaldson, L. (1997). Toward a stewardship theory of management. Academy of Management review, 22(1):20-47.

Dirks, K. T. (2000). Trust in leadership and team performance: Evidence from ncaa basketball. Journal of applied psychology, 85(6):1004.

Flynn, C. B., Smither, J. W., and Walker, A. G. (2016). Exploring the relationship between leaders core self-evaluations and subordinates perceptions of servant leadership: A field study. Journal of Leadership \& Organizational Studies, 23(3):260-271.

Fung, H. P. and Cheng, S. (2016). The influence of team building \& participation on team trust, team cohesion and project performance among project managers in malaysia.

Garbarino, E. and Johnson, M. S. (1999). The different roles of satisfaction, trust, and commitment in customer relationships. the Journal of Marketing, pages 70-87.
Goh, S.-K. and Low, B. Z.-J. (2013). The influence of servant leadership towards organizational commitment: The mediating role of trust in leaders. International Journal of Business and Management, 9(1):17.

Greenleaf, R. K. (1977). Servant leadership.

Greenleaf, R. K., Frick, D. M., and Spears, L. C. (1996). On becoming a servant-leader. Number D10 297.

Gunia, B. C., Brett, J. M., Nandkeolyar, A. K., and Kamdar, D. (2011). Paying a price: Culture, trust, and negotiation consequences. Journal of applied psychology, 96(4):774.

Hoch, J. E., Bommer, W. H., Dulebohn, J. H., and Wu, D. (2016). Do ethical, authentic, and servant leadership explain variance above and beyond transformational leadership? a meta-analysis. Journal of Management, page 0149206316665461.

Joseph, E. E. and Winston, B. E. (2005). A correlation of servant leadership, leader trust, and organizational trust. Leadership \& Organization Development Journal, 26(1):6-22.

Joslin, R. and Müller, R. (2016). The relationship between project governance and project success. International journal of project management, 34(4):613-626.

Judge, T. A., Erez, A., Bono, J. E., and Thoresen, C. J. (2003). The core self-evaluations scale: Development of a measure. Personnel psychology, 56(2):303-331.

Judge, T. A. and Kammeyer-Mueller, J. D. (2011). Implications of core self-evaluations for a changing organizational context. Human Resource Management Review, 21(4):331-341.

Klein, C., DiazGranados, D., Salas, E., Le, H., Burke, C. S., Lyons, R., and Goodwin, G. F. (2009). Does team building work? Small Group Research, 40(2):181-222.

Miao, Q., Newman, A., Schwarz, G., and Xu, L. (2014). Servant leadership, trust, and the organizational commitment of public sector employees in china. Public Administration, 92(3):727-743.

Moorman, C., Deshpande, R., and Zaltman, G. (1993). Factors affecting trust in market research relationships. the Journal of Marketing, pages 81-101.

Parris, D. L. and Peachey, J. W. (2013). A systematic literature review of servant leadership theory in organizational contexts. Journal of business ethics, 113(3):377-393.

Robey, D., Smith, L. A., and Vijayasarathy, L. R. (1993). Perceptions of conflict and success in information systems development projects. Journal of Management Information Systems, 10(1):123-140.

Rousseau, D. M., Sitkin, S. B., Burt, R. S., and Camerer, C. (1998). Not so different after all: A cross-discipline view of trust. Academy of management review, 23(3):393-404.

Russell, R. F. and Gregory Stone, A. (2002). A review of servant leadership attributes: Developing a practical model. Leadership E Organization Development Journal, 23(3):145157. 
Sendjaya, S. and Pekerti, A. (2010). Servant leadership as antecedent of trust in organizations. Leadership $\mathcal{E}$ Organization Development Journal, 31(7):643-663.

Seto, S. and Sarros, J. C. (2016). Servant leadership influence on trust and quality relationship in organizational settings. International Leadership Journal, 8(3).

Shrnhur, A. J., Levy, O., and Dvir, D. (1997). Mapping the dimensions of project success. Project management journal, 28(2):5-13.

Smith, J. P. and Rybkowski, Z. (2012). Literature review on trust and current construction industry trends. In 20th Annual Conference of the International Group for Lean Construction. San Diego, USA, pages 18-20.

Spears, L. (1996). Reflections on robert k. greenleaf and servant-leadership. Leadership $\mathcal{E}$ organization development journal, 17(7):33-35.

Spears, L. C. and Wagner-Marsh, F. (1998). Insights on leadership: Service, stewardship, spirit, and servant-leadership.

Tannenbaum, S. I., Beard, R. L., and Salas, E. (1992). Team building and its influence on team effectiveness: An examination of conceptual and empirical developments. In Advances in psychology, volume 82, pages 117-153. Elsevier.
Timiyo, A. J. and Yeadon-Lee, A. (2016). Universality of servant leadership. International Leadership Journal, 8(3):3-22.

Turner, J. R. and Müller, R. (2005). The project manager's leadership style as a success factor on projects: A literature review. Project Management Institute.

Van Dierendonck, D. and Nuijten, I. (2011). The servant leadership survey: Development and validation of a multidimensional measure. Journal of business and psychology, 26(3):249-267.

Van Dierendonck, D., Sousa, M., Gunnarsdóttir, S., Bobbio, A., Hakanen, J., Pircher Verdorfer, A., Cihan Duyan, E., and Rodriguez-Carvajal, R. (2017). The cross-cultural invariance of the servant leadership survey: A comparative study across eight countries. Administrative Sciences, 7(2):8.

Wong, P. T. and Page, D. (2003). Servant leadership: An opponent-process model and the revised servant leadership profile. In Proceedings of the Servant Leadership Research Roundtable. Citeseer.

Woodman, R. W. and Sherwood, J. J. (1980). Effects of team development intervention: A field experiment. The Journal of Applied Behavioral Science, 16(2):211-227. 